\title{
Carbon isotopic evidence for microbial control of carbon supply to Orca Basin at the seawater-brine interface
}

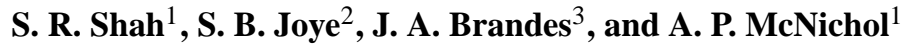 \\ ${ }^{1}$ Geology and Geophysics Department, Woods Hole Oceanographic Institution, Woods Hole, MA 02543, USA \\ ${ }^{2}$ Department of Marine Sciences, University of Georgia, Athens, GA 30602-3636, USA \\ ${ }^{3}$ Skidaway Institute for Oceanography, Savannah, GA 31411, USA
}

Correspondence to: S. R. Shah (sshah@whoi.edu)

Received: 27 November 2012 - Published in Biogeosciences Discuss.: 13 December 2012

Revised: 1 April 2013 - Accepted: 10 April 2013 - Published: 13 May 2013

\begin{abstract}
Orca Basin, an intraslope basin on the TexasLouisiana continental slope, hosts a hypersaline, anoxic brine in its lowermost $200 \mathrm{~m}$ in which limited microbial activity has been reported. This brine contains a large reservoir of reduced and aged carbon, and appears to be stable at decadal time scales: concentrations and isotopic composition of dissolved inorganic (DIC) and organic carbon (DOC) are similar to measurements made in the 1970s. Both DIC and DOC are more "aged" within the brine pool than in overlying water, and the isotopic contrast between brine carbon and seawater carbon is much greater for DIC than DOC. While the stable carbon isotopic composition of brine DIC points towards a combination of methane and organic carbon remineralization as its source, radiocarbon and box model results point to the brine interface as the major source region for DIC, allowing for only limited oxidation of methane diffusing upwards from sediments. This conclusion is consistent with previous studies that identify the seawater-brine interface as the focus of microbial activity associated with Orca Basin brine. Isotopic similarities between DIC and DOC suggest a different relationship between these two carbon reservoirs than is typically observed in deep ocean basins. Radiocarbon values implicate the seawater-brine interface region as the likely source region for DOC to the brine as well as DIC.
\end{abstract}

\section{Introduction}

Active and diverse microbial communities have been reported in deep-sea brines of the Gulf of Mexico, Red Sea and Mediterranean Sea (reviewed in Antunes et al., 2011; Joye et al., 2010). These anoxic brines test the limits of microbial adaptation across a range of temperatures, salinities and $\mathrm{pH}$ conditions. Orca Basin, a deep basin located on the TexasLouisiana slope, is the largest brine pool yet identified in the Gulf of Mexico (Pilcher and Blumstein, 2007; Shokes et al., 1977; Trabant and Presley, 1978). Although moderate conditions are found in Orca Basin brine compared to other deepsea brines (Antunes et al., 2011; Joye et al., 2005), studies of microbial abundance and activity in Orca Basin have concluded that very little physiological activity can be measured below the seawater-brine interface (Dickins and Van Vleet, 1992; LaRock et al., 1979; Tuovila et al., 1987; Wiesenburg et al., 1985). This lack of microbial activity stands in contrast to other Gulf of Mexico brines in the Gulf of Mexico (Joye et al., 2009, 2010).

The continental slope of the northern Gulf of Mexico is characterized by numerous basins and pockmarks extending from the shelf edge to the basin floor (Bouma and Bryant, 1994, and references therein). This complex bathymetry is produced by the interaction of sediments and underlying salt, which drives salt deformation (Humphris, 1978), a process also associated with brine formation and brine seepage along seafloor fault networks (Reilly et al., 1996; Roberts and Carney, 1997). Although brine seepage is considered widespread in the northwestern Gulf of Mexico, only a few brine pools have been detected and studied (Joye et al., 2005; 
Macdonald et al., 1990; Shokes et al., 1977). Orca Basin, an intraslope depression at a water depth of approximately $2000 \mathrm{~m}$ on the northwestern continental slope of the Gulf of Mexico, was the first among these to be identified (Shokes et al., 1977; Trabant and Presley, 1978). Below $2240 \mathrm{~m}$ depth, the basin is occupied by an anoxic, hypersaline brine. Both the geochemistry of the brine and composition of underlying sediments indicate the $\sim 200 \mathrm{~m}$ thick brine originates from dissolution of a nearby salt exposure and lateral advection of brine to the basin (Addy and Behrens, 1980; Pilcher and Blumstein, 2007; Sheu et al., 1988; Shokes et al., 1977; Trabant and Presley, 1978). This formation mechanism is unlike many other Gulf of Mexico brines that have in situ sources of dissolved ions and reduced gases (Joye et al., 2005, 2009, 2010).

Within the Orca Basin brine, oxygen and nitrate are not detectable while phosphate concentrations are elevated compared to overlying seawater resulting from organic-matter decomposition (Leventer et al., 1983; Shokes et al., 1977; Van Cappellen et al., 1998). Sulfate concentrations, however, are not depleted within the brine suggesting a limited role for microbial sulfate reduction in the anoxic brine (Hurtgen et al., 1999; Leventer et al., 1983; Trefry et al., 1984; Wiesenburg et al., 1985) despite high concentrations of organic carbon and methane (Sackett et al., 1979). The most intense microbial activity is focused in the seawater-brine interface region (LaRock et al., 1979; Sheu et al., 1988; Van Cappellen et al., 1998; Wiesenburg et al., 1985), a particle trap where successive depletion of oxygen, nitrate and oxidized manganese has been observed (Trefry et al., 1984; Van Cappellen et al., 1998) along with narrowly defined peaks of methane, ethane, propane and hydrogen sulfide concentrations (Wiesenburg et al., 1985). These authors propose that accumulation of reduced gases and anoxia within the brine result from the long residence time of brine in Orca Basin combined with slow in situ decomposition of organic carbon (Wiesenburg et al., 1985).

The onset of brine accumulation in Orca Basin is thought to be signaled by a transition from shallow, black anoxic sediments to more deeply buried gray sediments. This transition, reported in both slope sediments and in deeper basin sediments (Addy and Behrens, 1980; Leventer et al., 1983; Meckler et al., 2008; Northam et al., 1981) has been dated by three methods: radiocarbon analysis of total carbonate (Addy and Behrens, 1980); radiocarbon analysis of foraminifera (Leventer et al., 1983; Meckler et al., 2008); and biostratigraphy (Leventer et al., 1983), yielding similar ages of approximately 7900 to 8500 calendar years for Orca Basin brine.

Here we use radiocarbon measurements of dissolved inorganic (DIC) and organic carbon (DOC) and box modeling to document slow, cumulative microbial processes driving organic carbon cycling within the basin.

\section{Material and methods}

\subsection{Sampling}

Brine from the southern lobe of Orca Basin and overlying seawater was sampled by CTD rosette at $26^{\circ} 54.5^{\prime} \mathrm{N}$, $91^{\circ} 20.1^{\prime} \mathrm{W}$ from the R/V Atlantis during cruise AT182. Whole seawater was collected for radiocarbon analysis of DIC following the NOSAMS DIC sampling protocol (http://www.whoi.edu/NOSAMS_DIC_collection, accessed in 2010). Briefly, $500 \mathrm{~mL}$ of seawater was collected in pre-combusted glass bottles after thorough rinsing with sample seawater, poisoned with mercuric chloride and sealed with greased, ground-glass stoppers. Filtered DOC samples were collected directly from Niskin bottles into $1 \mathrm{~L}$ amber bottles through an in-line, pre-combusted $47 \mathrm{~mm}$ Whatman GF/F filter. Multiple filters were necessary to collect 200 to $300 \mathrm{~mL}$ brine samples. DOC bottles were capped with Teflon-lined lids and stored at $-20^{\circ} \mathrm{C}$ until analysis.

\subsection{DIC and DOC concentrations}

Samples for DIC analysis were filter-sterilized $(0.2 \mu \mathrm{m})$ and stored in gas-tight $2 \mathrm{~mL}$ autosampler vials at $4^{\circ} \mathrm{C}$ prior to analysis (Brandes, 2009) using liquid chromatographyisotope ratio-monitoring mass spectrometry (LC-IRMS) with a Delta V Plus. Samples were calibrated against sodium bicarbonate standards. Samples for DOC analysis were filtersterilized on board the ship $\left(0.2 \mu \mathrm{m}\right.$ Target ${ }^{\circledR}$ filters $)$ and stored frozen at $-20^{\circ} \mathrm{C}$ prior to analysis using a Shimadzu TOC-V high temperature catalytic oxidation system (Joye et al., 2010). As a precautionary measure, the Target ${ }^{\circledR}$ filters were rinsed by running $10-15 \mathrm{~mL}$ of UV-oxidized milliQ water through the filters and dried by passing $5-10 \mathrm{~mL}$ of dry sterile $(0.2 \mu \mathrm{m}$ filtered $)$ air through the filter. Blanks for DOC, UV-oxidized milliQ filtered through similarly cleaned $0.2 \mu \mathrm{m}$ Target ${ }^{\circledR}$ filters, were collected along side DOC samples in the field and run in the laboratory; blanks were consistently less than $0.2 \mu \mathrm{M}$.

\section{$2.3 \quad \delta^{13} \mathrm{C}$ and $\Delta^{14} \mathrm{C}$ analysis}

Stable carbon isotopic analysis and radiocarbon analysis of DIC and DOC was performed at the National Ocean Sciences Accelerator Mass Spectrometry (NOSAMS) facility. Inorganic carbon was extracted from DIC samples with the water-stripping method (McNichol et al., 1994). $\delta^{13} \mathrm{C}$ values were determined on a split of the sample $\mathrm{CO}_{2}$ by dual-inlet Optima IRMS, and the remainder of the $\mathrm{CO}_{2}$ was converted to graphite for radiocarbon analysis by AMS. This method has been successfully used to analyze DIC from brine samples previously (e.g., Ma et al., 2005; Mikucki et al., 2009). Ongoing analysis of reproducibility across all sample types at NOSAMS indicates measurement uncertainty is $\pm 0.05 \%$ o for $\delta^{13} \mathrm{C}$ values and $\pm 4.9 \%$ for $\Delta^{14} \mathrm{C}$ of modern samples 
(Elder et al., 1998; Jenkins et al., 2010). Independent $\delta^{13} \mathrm{C}$ measurements of separate DIC samples were performed by LC-IRMS (as described in Sect. 2.2; Brandes, 2009) at Skidaway Institute of Oceanography (SkIO). Reproducibility of DIC standards by LC-IRMS method was $\pm 0.04 \%$.

DOC was converted to $\mathrm{CO}_{2}$ by the UV oxidation method (Beaupré et al., 2007). Brine samples were diluted with preirradiated MilliQ water (dilution factors: 2.9,3.0) and a split of sample $\mathrm{CO}_{2}$ was reserved for $\delta^{13} \mathrm{C}$ analysis by dual-inlet Prism IRMS. The remainder was graphitized for radiocarbon analysis by AMS. Sample results are all corrected for process blanks determined using the method of Currie et al. (2000) and Santos et al. (2007). Measurement of modern and dead standards indicates processing introduces the equivalent of $0.21 \pm 0.2 \mu$ mol modern carbon and $0.33 \pm 0.28 \mu \mathrm{mol}$ dead carbon, and we observe an overall reproducibility of $\pm 0.3 \%$ o for $\mathrm{DO}^{13} \mathrm{C}$ and \pm 7 to $10 \%$ for modern $\mathrm{DO}^{14} \mathrm{C}$.

\section{Results}

\subsection{Salinity and dissolved oxygen}

Salinity and dissolved oxygen profiles are illustrated in Fig. 1. Oxygen depletion begins above the sharp salinity increase at approximately $2100 \mathrm{~m}$, defining the upper limit of the seawater-brine interface region. Salinity increases sharply to the brine value at approximately $2240 \mathrm{~m}$ resulting in an estimated thickness of $140 \mathrm{~m}$ for the seawaterbrine transition region. This is the same thickness reported by Sackett et al. (1979), suggesting the interface is very stable with little change observed since the late 1970s.

\subsection{Dissolved Inorganic Carbon}

DIC concentrations also show a similar pattern to that observed in 1976-1977 with a doubling of concentrations between overlying seawater (2.0-2.1 mM) and brine (3.9$4.1 \mathrm{mM}$; Sackett et al., 1979). This transition occurs over approximately $50 \mathrm{~m}$, paralleling salinity rather than oxygen concentration (Fig. 1a). For both seawater and brine, DIC concentrations reported by Sackett et al. (1979) are slightly higher and more variable than our values (Fig. 1a). Smallscale gradients in DIC concentration are not expected because Orca Basin brine is convectively mixed (Shokes et al., 1977; Wiesenburg et al., 1985). Our low-precision estimates of DIC concentration obtained from two brine depths during $\mathrm{CO}_{2}$ extraction for radiocarbon analysis also agree within analytical uncertainty arguing against DIC gradients within the brine. Combined, these observations give confidence to our DIC profile with its absence of small-scale variability throughout the depth profile.

By all three measures, brine DIC is significantly depleted in ${ }^{13} \mathrm{C}$ relative to overlying seawater (Table 1 , Fig. 1b), indicating substantial contributions from remineralized organic carbon or methane. Sackett et al. (1979) present a detailed

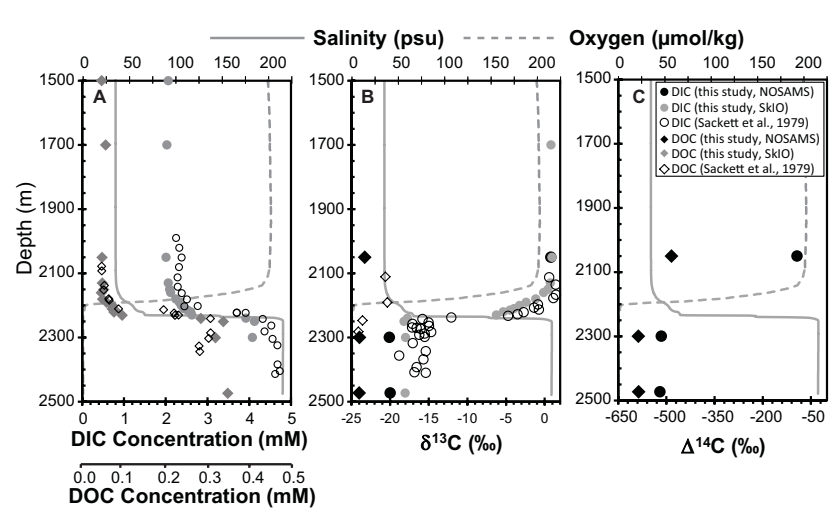

Fig. 1. Depth profiles of salinity (gray solid line) and dissolved oxygen concentrations (gray dashed line) are plotted for the south basin of Orca Basin brine along with (A) concentrations of DIC (filled circles, this study; open circles from Sackett et al., 1979) and DOC (filled diamonds, this study; open diamonds from Sackett et al., 1979); (B) $\delta^{13} \mathrm{C}$ values of DIC and DOC; and (C) $\Delta^{14} \mathrm{C}$ values for DIC and DOC. Error bars are smaller than symbols for this study ( $\pm 0.04-0.5 \%$ ofor $\delta^{13} \mathrm{C}$ values and $\pm 1-3 \%$ o for $\Delta^{14} \mathrm{C}$ values).

profile documenting the transition between overlying seawater and brine $\delta^{13} \mathrm{C}$ values, and here we describe the present isotopic state of the DIC reservoir using two independent methods: $\mathrm{CO}_{2}$ extraction followed by offline $\delta^{13} \mathrm{C}$ analysis by dual-inlet IRMS (NOSAMS) and LC-IRMS (SkIO). Both methods indicate a DIC reservoir that is more depleted in ${ }^{13} \mathrm{C}$ than any value reported by Sackett et al. (1979). Similar to DIC concentrations, brine $\delta^{13} \mathrm{C}_{\mathrm{DIC}}$ values measured at NOSAMS agree within analytical uncertainty. $\delta^{13} \mathrm{C}_{\text {DIC }}$ values determined at SkIO also agree closely within the brine, which contrasts with the $\sim 4 \%$ range observed previously (Fig. 1). As described above, the small-scale variability recorded by Sackett et al. (1979) is not expected within a well-mixed brine lending credibility to our more recent analyses.

Despite internal consistency, our $\delta^{13} \mathrm{C}_{\mathrm{DIC}}$ values are significantly different than those reported previously and also significantly different from each other (Fig. 1b). We believe the 2 or $4 \%$ difference is more likely to be a result of a methodological bias rather than reflect a decadally dynamic DIC reservoir. Our parallel $\delta^{13} \mathrm{C}$ measurements may differ due to the difference in chemical composition between brine samples and seawater calibration standards. Since we cannot reconcile our NOSAMS $\delta^{13} \mathrm{C}_{\mathrm{DIC}}$ values $(-20.0 \pm 0.05 \%$ ) with values measured at SkIO $(-18.1 \pm 0.1 \%$ ) , or the average $\delta^{13} \mathrm{C}_{\mathrm{DIC}}$ value $(-16.4 \pm 1 \%$ ) reported by Sackett et al. (1979), we include the average $\delta^{13} \mathrm{C}_{\text {DIC }}$ value from both of our measurement methods as well as that reported by Sackett et al. (1979) in calculations and the Discussion below.

The radiocarbon contents of brine DIC at 2300 and $2473 \mathrm{~m}$ depth agree within analytical uncertainty, showing no variation with depth (Table 1, Fig. 1c). Our values are in general 
Table 1. Isotopic composition of Orca Basin brine and overlying water.

\begin{tabular}{|c|c|c|c|c|c|c|c|c|}
\hline Depth (m) & $\delta^{13} \mathrm{C}_{\text {DIC }}(\% \circ)$ & \pm & $\delta^{13} \mathrm{C}_{\mathrm{DOC}}(\%)$ & \pm & $\Delta^{14} \mathrm{C}_{\text {DIC }}(\%)$ & \pm & $\Delta^{14} \mathrm{C}_{\mathrm{DOC}}(\% \circ)$ & \pm \\
\hline $2050^{\mathrm{b}}$ & 0.93 & 0.04 & & & & & & \\
\hline $2050^{\mathrm{a}}$ & 0.81 & 0.05 & -23.3 & 0.3 & -93.1 & 3.6 & -481.9 & 2.4 \\
\hline $2130^{\mathrm{b}}$ & 0.72 & 0.04 & & & & & & \\
\hline $2150^{\mathrm{b}}$ & 0.41 & 0.04 & & & & & & \\
\hline $2160^{\mathrm{b}}$ & -0.13 & 0.04 & & & & & & \\
\hline $2180^{\mathrm{b}}$ & -1.17 & 0.04 & & & & & & \\
\hline $2190^{\mathrm{b}}$ & -2.40 & 0.04 & & & & & & \\
\hline $2200^{\mathrm{b}}$ & -3.27 & 0.04 & & & & & & \\
\hline $2210^{\mathrm{b}}$ & -3.97 & 0.04 & & & & & & \\
\hline $2215^{\mathrm{b}}$ & -4.49 & 0.04 & & & & & & \\
\hline $2220^{\mathrm{b}}$ & -5.35 & 0.04 & & & & & & \\
\hline $2230^{\mathrm{b}}$ & -6.25 & 0.04 & & & & & & \\
\hline $2240^{\mathrm{b}}$ & -17.75 & 0.04 & & & & & & \\
\hline $2250^{\mathrm{b}}$ & -18.20 & 0.04 & & & & & & \\
\hline $2300^{\mathrm{b}}$ & -17.99 & 0.04 & & & & & & \\
\hline $2300^{\mathrm{a}}$ & -20.07 & 0.05 & -24.0 & 0.3 & -515.5 & 2.5 & -586.3 & 1.8 \\
\hline $2473^{b}$ & -18.05 & 0.04 & & & & & & \\
\hline $2473^{\mathrm{a}}$ & -19.97 & 0.05 & -24.0 & 0.3 & -520.0 & 2.1 & -587.1 & 1.7 \\
\hline
\end{tabular}

${ }^{a}$ Analyzed at NOSAMS. ${ }^{b}$ Analyzed at SkIO.

agreement with $\Delta{ }^{14} \mathrm{C}_{\mathrm{DIC}}$ values reported previously (decay corrected to $-509 \%$ o, $-496 \%$ and $-492 \%$ from Sackett et al., 1979; Stuiver and Polach, 1977), although these values were not reported with sample depths. Both the $\Delta^{14} \mathrm{C}$ and $\delta^{13} \mathrm{C}$ values of DIC from overlying seawater are similar to World Ocean Circulation Experiment (WOCE) values from 2000-3000 m depth in the North Atlantic (WOCE line A22, 1997).

\subsection{Dissolved organic carbon}

DOC concentrations within the brine $(320-349 \mu \mathrm{M})$ are greater than those in the overlying seawater $(50-59 \mu \mathrm{M})$ by a factor of seven and are in good agreement with DOC concentrations reported by Sackett et al. (1979; Fig. 1a). The $\delta^{13} \mathrm{C}$ values of DOC are also very similar to those reported by Sackett et al. (1979) and do not show any variation with depth. The carbon isotopic contrast between DOC in the brine and overlying seawater is considerably smaller than for DIC (Table 1, Fig. 1b and c). The DOC from overlying seawater is also isotopically similar to DOC measured in the North Atlantic at similar depths (Druffel et al., 1992).

\section{Discussion}

Comparison between our isotopic results and similar values reported three decades ago (Sackett et al., 1979) suggests that the Orca Basin lacks a dynamic carbon cycle. Multiple studies of the sediments underlying Orca Basin have converged on a 7900 to $8500 \mathrm{yr}$ timescale for the establishment of anoxic, hypersaline conditions in the basin (Addy and Behrens, 1980; Leventer et al., 1983; Meckler et al., 2008). For this study, we compared our radiocarbon values with the most recent foram record reported by Meckler et al. (2008) because it includes a foraminiferal radiocarbon date in close proximity to the black-gray sediment transition depth and because radiocarbon analysis of individual foraminiferal species has confirmed stratigraphic continuity in this location (Flower et al., 2011). Adjusting these reported radiocarbon ages by the more recent, smaller reservoir age from the nearby Flower Garden Banks (Wagner et al., 2009) results in an $8700 \pm 100 \mathrm{yr}$ calendar age for Orca Basin brine. Establishment of the brine, however, is not necessarily coupled to the establishment of its dissolved carbon reservoir. This brine age requires a greater depletion of ${ }^{14} \mathrm{C}$ than was actually measured in brine DIC, pointing towards the input of more modern carbon to the DIC reservoir in the Orca Basin.

\subsection{Conservative mixing of brine and seawater end-members}

The depth profiles of DIC and DOC concentrations closely parallel that of salinity through the seawater-brine interface of Orca Basin (Fig. 1a), and Fig. 2 illustrates the relationship between DIC, DOC and salinity across this interface. Conservative mixing between seawater and a brine end-member source is implied by the strong linearity observed between salinity and DIC as well as salinity and DOC concentrations. Small deviations from the conservative mixing line (Fig. 2) do allow for a limited DIC source in the low-salinity region of the seawater-brine interface where extensive organic 

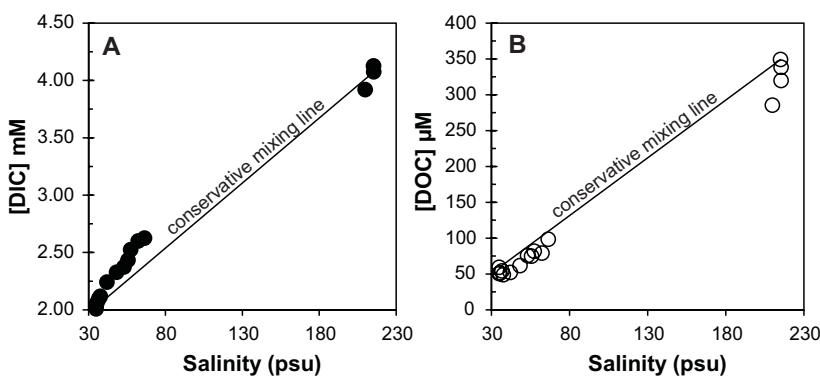

Fig. 2. Mixing diagrams for (A) DIC and (B) DOC concentrations across the seawater-brine interface plotted along with solid lines which represent expected concentrations from conservative mixing of brine and seawater end-members.

matter degradation has been reported (Tribovillard et al., 2008; Wong et al., 1985) as well as nonconservative behavior of DOC within the brine.

The isotopic composition of this brine end-member can be calculated by constructing an isotopic mixing model. Solving the following equations:

$m_{\text {measured }}=m_{\text {seawater }}+m_{\text {brine }}$

$m_{\text {measured }} \cdot \delta_{\text {measured }}=m_{\text {seawater }} \cdot \delta_{\text {seawater }}+m_{\text {brine }} \cdot \delta_{\text {brine }}$,

$m_{\text {measured }} \cdot \Delta_{\text {measured }}=m_{\text {seawater }} \cdot \Delta_{\text {seawater }}+m_{\text {brine }} \cdot \Delta_{\text {brine }}$,

where the concentration ( $\left.m_{\text {brine }}\right), \delta^{13} \mathrm{C}$ value $\left(\delta_{\text {brine }}\right)$ and $\Delta^{14} \mathrm{C}$ value ( $\Delta_{\text {brine }}$ ) of the brine end-member calculated using the average measured brine values for $m_{\text {measured }}, \delta_{\text {measured }}$ and $\Delta_{\text {measured }}$ and values from overlying seawater at a depth of $2050 \mathrm{~m}$ for $m_{\text {seawater }}, \delta_{\text {seawater }}$ and $\Delta_{\text {seawater }}$, yields an $\delta^{13} \mathrm{C}$ estimate of $-40 \pm 3 \%$ (NOSAMS) or $-36 \pm 2 \%$ (SkIO) and a $\Delta^{14} \mathrm{C}$ estimate of $-930 \pm 64 \%$. Using the $\delta^{13} \mathrm{C}_{\text {DIC }}$ values reported by Sackett et al. (1979) indicate a brine endmember that is a bit less ${ }^{13} \mathrm{C}$ depleted $(-33 \pm 2 \%$ o). This approach, similar to that utilized by Sackett et al. (1979), suggests that brine DIC is supplied by a source depleted in both ${ }^{13} \mathrm{C}$ and ${ }^{14} \mathrm{C}$. The $\delta{ }^{13} \mathrm{C}$ value of the brine end-member likely reflects a combination of POC remineralization with typical marine values of -21 to $-22 \%$ (Northam et al., 1981; Sackett et al., 1979) and oxidation of methane having a $\delta^{13} \mathrm{C}$ value of -72 to $-75 \%$ o (Sackett et al., 1979; Wiesenburg et al., 1985). This conservative mixing model, however, is unable to account for the time-evolving nature of ${ }^{14} \mathrm{C}$ concentration and is most representative of a single modern mixing event. The three similar estimates of brine age from slope (Leventer et al., 1983; Meckler et al., 2008) and deep basin sediments (Addy and Behrens, 1980) suggest that the current brine thickness accumulated quickly, making a single modern mixing event unlikely. If any single episode (i.e., of short enough duration that DIC does not "age" significantly) mixed seawater and end-member brine to produce the current brine composition, it would have occurred at the onset of brine accumulation, 8700 calendar years (or 8078 radiocarbon years) ago. However, a long-ago mixing event is incompatible with the radiocarbon age of brine DIC $(\sim 5800$ radiocarbon years), which is younger than the age of the brine. Thus we conclude that an isotopic mixing model cannot accurately represent the radiocarbon content of a brine end-member and that the true brine DIC source is likely to be significantly more modern than the value calculated above.

Although it does not represent the ${ }^{14} \mathrm{C}$ contents of reduced carbon sources which ultimately contribute DIC to Orca Basin brine, $\delta^{13} \mathrm{C}$ results from the isotopic mixing model highlight the significant contribution that microbial oxidation of reduced carbon compounds make to the inorganic carbon pool in Orca Basin. They also do not reveal any one dominant source of reduced carbon, rather suggesting a combination of methane and sinking organic carbon. A mass balance calculation according to the following equation:

$$
\begin{aligned}
& \delta^{13} \mathrm{C}_{\text {brine }}=\frac{[\mathrm{DIC}]_{\text {seawater }}}{[\mathrm{DIC}]_{\text {brine }}} \cdot \delta^{13} \mathrm{C}_{\text {seawater }} \\
& +f_{\mathrm{POC}} \frac{\left([\mathrm{DIC}]_{\text {brine }}-[\mathrm{DIC}]_{\text {seawater }}\right)}{[\mathrm{DIC}]_{\text {brine }}} \cdot \delta^{13} \mathrm{C}_{\mathrm{POC}} \\
& +\left(1-f_{\mathrm{POC}}\right) \cdot \frac{\left([\mathrm{DIC}]_{\text {brine }}-[\mathrm{DIC}]_{\text {seawater }}\right)}{[\mathrm{DIC}]_{\text {brine }}} \cdot \delta^{13} \mathrm{C}_{\text {methane }} \cdot
\end{aligned}
$$

Using the expected $\delta^{13} \mathrm{C}$ values for methane and sinking POC described above indicates $65 \pm 6 \%$ (NOSAMS) or $72 \pm 6 \%$ (SkIO) of brine end-member DIC must come from POC remineralization and the remainder from methane oxidation. Using the average $\delta^{13} \mathrm{C}_{\mathrm{DIC}}$ value reported by Sackett et al. (1979) results in an estimate of $80 \pm 8 \%$ of brine DIC deriving from $\mathrm{POC}$ remineralization.

\subsection{Box-model estimates of brine DIC sources}

Microbially mediated DIC addition to Orca Basin argues against the model of a single mixing episode and instead implies a slow accumulation of excess DIC and therefore an uncoupling between brine formation and DIC accumulation within the brine. To better capture this model of DIC buildup and constrain the radiocarbon age of the microbially contributed DIC, we constructed a box model to represent the evolution of DIC during the $8700 \mathrm{yr}$ history of Orca Basin brine. Brine DIC can be contributed by the remineralization of sinking organic carbon ("modern", with an age of contemporaneous marine organic carbon from photosynthesis in the mixed layer), methane from the seawater-brine interface ("modern") or methane diffusing upwards from sediments ("aged"). We assume a constant rate of DIC increase added to an initial DIC concentration and isotopic composition equivalent to seawater overlying the Orca Basin brine. We do not explicitly include molecular diffusion as only picomolar DIC loss can be expected over the entire lifetime of the brine with a molecular diffusivity of $0.5 \times 10^{-9} \mathrm{~m}^{2} \mathrm{~s}^{-1}$ (Zeebe, 2011). Eddy diffusion is likely to have a somewhat greater effect than molecular diffusion, although the sharp and stable DIC 
gradient at the brine interface (Fig. 1a) argues against any large diffusive DIC losses from the Orca Basin brine. Because we cannot measure eddy diffusivity for the brine interface and because the large density contrast between the brine and overlying seawater will inhibit turbulent diffusion making it unlikely to have a significant influence on the evolution of the DIC reservoir, we do not include DIC loss due to eddy diffusion in the box model. ${ }^{14} \mathrm{C}$ decay is incorporated into each timestep following Eq. (7), and the fraction of POC and methane added at each time increment is determined by the fractions calculated in Sect. 4.1. We prescribe the $\Delta^{14} \mathrm{C}$ value of sinking POC over the lifetime of the brine as atmospheric $\Delta^{14} \mathrm{C}$ values according to IntCal09 (Reimer et al., 2009) offset by the reservoir age from the nearby Flower Garden Banks ( $-53.2 \pm 1 \%$; Wagner et al., 2009) to account for atmospheric ${ }^{14} \mathrm{C}$ variability through time and solve iteratively for the $\Delta^{14} \mathrm{C}$ of methane. The following equations describe the concentration and isotopic composition of DIC at time $t$ in the box model:

$$
\begin{aligned}
{[\mathrm{DIC}]_{t} } & =[\mathrm{DIC}]_{t-1}+\frac{[\mathrm{DIC}]_{\text {final }}-[\mathrm{DIC}]_{\text {initial }}}{t_{\text {final }}-t_{\text {initial }}}, \\
\delta^{13} \mathrm{C}_{t} & =\frac{[\mathrm{DIC}]_{t-1} \cdot \delta^{13} \mathrm{C}_{t-1}}{[\mathrm{DIC}]_{t}} \\
& +\frac{f \cdot\left([\mathrm{DIC}]_{t}-[\mathrm{DIC}]_{t-1}\right) \cdot \delta^{13} \mathrm{C}_{\mathrm{POC}}}{[\mathrm{DIC}]_{t}} \\
& +\frac{(1-f) \cdot\left([\mathrm{DIC}]_{t}-[\mathrm{DIC}]_{t-1}\right) \cdot \delta^{13} \mathrm{C}_{\text {methane }}}{[\mathrm{DIC}]_{t}},
\end{aligned}
$$

$\left[\Delta^{14} \mathrm{C}_{t}\right]_{\mathrm{AGED}}=\left[\left(\frac{\Delta^{14} \mathrm{C}_{t}}{1000}+1\right) \cdot e^{\lambda(-5)}-1\right] \cdot 1000$,

$$
\begin{aligned}
\Delta^{14} \mathrm{C}_{t} & =\frac{[\mathrm{DIC}]_{t-1} \cdot\left[\Delta^{14} \mathrm{C}_{t-1}\right]_{\mathrm{AGED}}}{[\mathrm{DIC}]_{t}} \\
& +\frac{f \cdot\left([\mathrm{DIC}]_{t}-[\mathrm{DIC}]_{t-1}\right) \cdot \Delta{ }^{14} \mathrm{C}_{\mathrm{POC}}}{[\mathrm{DIC}]_{t}} \\
& +\frac{(1-f) \cdot\left([\mathrm{DIC}]_{t}-[\mathrm{DIC}]_{t-1}\right) \cdot \Delta{ }^{14} \mathrm{C}_{\text {methane }}}{[\mathrm{DIC}]_{t}} .
\end{aligned}
$$

Fig. 3, gray line). Considering the slightly ${ }^{14} \mathrm{C}$-depleted value compared to time-averaged $\mathrm{POC}$ and considering the uncertainties of this approach (Fig. 3, dashed lines), model results do not exclude a small contribution from the oxidization of aged methane diffusing into the brine from sediments (Wiesenburg et al., 1985). The importance of the brine interface as a potential DIC source to the brine below is suggested by the multiple studies that point toward high rates of microbial activity focused in this region (LaRock et al., 1979; Sheu et al., 1988; Van Cappellen et al., 1998; Wiesenburg et al., 1985) and that document extensive degradation of organic matter at the seawater-brine interface (Tribovillard et al., 2008; Wong et al., 1985). And the small deviation of DIC concentrations from a conservative mixing line (Fig. 2) compared to the deviations observed for alkalinity and $\mathrm{Mn}^{2+}$ (Van Cappellen et al., 1998) lend support to the low-salinity region of the interface being a slow, cumulative source of DIC.

Using the parameters in Table 2 (with either NOSAMS or SkIO value for final $\delta^{13} \mathrm{C}$ ) and a $5 \mathrm{yr}$ time resolution, this model calculates a $\Delta^{14} \mathrm{C}$ value of $-31 \pm 102 \%$ for DIC resulting from methane oxidation (Fig. 3). Substituting in the average $\delta^{13} \mathrm{C}_{\mathrm{DIC}}$ value reported by Sackett et al. (1979) changes the result by less than $1 \%$ o because the calculated methane source has very similar radiocarbon contents to the average prescribed POC source. It also does not increase uncertainty in the model output due to the larger uncertainties assigned to the $\delta^{13} \mathrm{C}$ values of POC and methane (Table 2). This "modern" result points to the brine interface as the dominant source region for methane that is oxidized by the microbial assemblage in Orca Basin, resulting in DIC with a radiocarbon value similar to sinking POC (time average: $-18 \%$,

\subsection{Isotopic composition and sources of brine DOC}

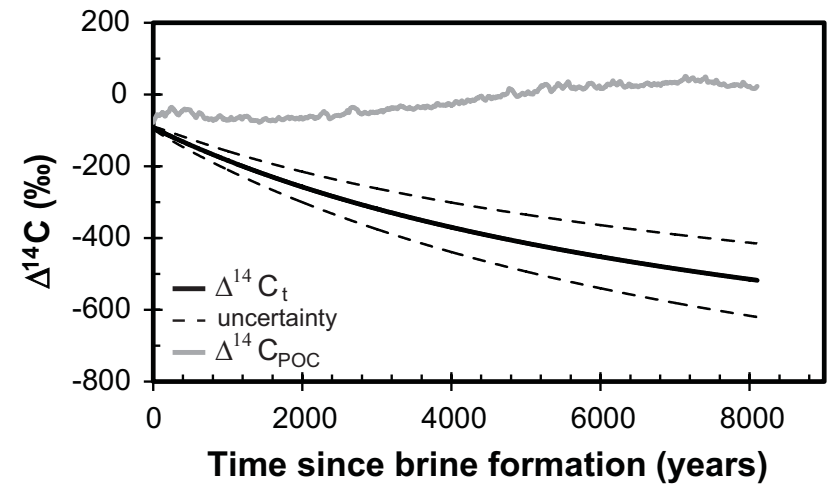

Fig. 3. Box modeled results for the $\Delta^{14} \mathrm{C}$ value of DIC (solid black line) over the 8078 radiocarbon-year history of Orca Basin brine
plotted along with dashed lines representing uncertainty in model results. The solid gray line represents $\Delta^{14} \mathrm{C}$ values of POC inreservoir age from the nearby Flower Garden Banks (Wagner et al., 2009).

In the seawater overlying Orca Basin, the contrast between the radiocarbon contents of DIC and DOC is $389 \%$, not significantly different from the 300-380\% contrasts observed at similar depths in the Arctic (Griffith et al., 2012), Atlantic, Pacific and Southern Oceans (Druffel and Bauer, 2000). Within the Orca Basin brine, however, the difference between the radiocarbon contents of DIC and DOC is much smaller ( $\sim 70 \%$, Table 1$)$. This smaller contrast implies sources and sinks of Orca Basin DOC that are distinct from deep-ocean refractory DOC despite $\delta^{13} \mathrm{C}$ values that are indistinguishable $\left(\delta^{13} \mathrm{C}_{\text {brineDOC }}-\delta^{13} \mathrm{C}_{\text {seawaterDOC }}=-0.7 \pm 1 \%\right.$ ) .

In addition to the similarity in radiocarbon contents, the $\delta^{13} \mathrm{C}$ values of brine DIC and brine DOC are also strikingly put driven by IntCal09 (Reimer et al., 2009) adjusted for a local 
Table 2. Box model parameters, values and uncertainties.

\begin{tabular}{|c|c|c|c|c|}
\hline Symbol & Parameter & Value & \pm & Source \\
\hline$t_{0}$ & initial time in years & 0 & & \\
\hline$t_{\mathrm{f}}$ & final time in years & 8078 & 74 & uncalibrated radiocarbon age of brine \\
\hline$[\mathrm{DIC}]_{0}(\mu \mathrm{M})$ & initial DIC concentration & 2006 & 20 & value from overlying seawater at $2063 \mathrm{~m}$ \\
\hline$[\mathrm{DIC}]_{\mathrm{f}}(\mu \mathrm{M})$ & final DIC concentration & 4086 & 41 & average brine [DIC] \\
\hline$\delta^{13} \mathrm{C}_{0}(\% \circ)$ & initial $\delta^{13} \mathrm{C}$ value & 0.81 & 0.01 & value from overlying seawater at $2050 \mathrm{~m}$ \\
\hline \multirow[t]{2}{*}{$\delta^{13} \mathrm{C}_{\mathrm{f}}(\% \circ)$} & final $\delta^{13} \mathrm{C}$ value & -20.02 & 0.01 & average brine $\delta^{13} \mathrm{C}_{\mathrm{DIC}}$ (NOSAMS) \\
\hline & & -18.08 & 0.11 & average brine $\delta^{13} \mathrm{C}_{\mathrm{DIC}}(\mathrm{SkIO})$ \\
\hline$\delta^{13} \mathrm{C}_{\mathrm{POC}}(\%)$ & sinking POC $\delta^{13} \mathrm{C}$ value & -22 & 1 & Holocene organic matter ${ }^{\mathrm{a}}$ \\
\hline$\delta^{13} \mathrm{C}_{\text {methane }}(\% o)$ & methane $\delta^{13} \mathrm{C}$ value & -74 & 2 & average methane values ${ }^{b}$ \\
\hline$f_{\text {POC-methane }}$ & fraction POC & 0.65 & 0.06 & calculated in Sect. 4.1, Eq. (4) \\
\hline$\lambda$ & $1 /$ true mean-life & $1 / 8267$ & & Stuiver and Polach (1977) \\
\hline$\Delta^{14} \mathrm{C}_{0}(\% \circ)$ & initial $\Delta^{14} \mathrm{C}$ value & -93.1 & 3.6 & value from overlying seawater at $2050 \mathrm{~m}$ \\
\hline$\Delta^{14} \mathrm{C}_{\mathrm{POC}}(\% \circ)$ & sinking POC $\Delta^{14} \mathrm{C}$ value & -53.2 & 1.0 & IntCal09 values ${ }^{c}$ minus reservoir age $\mathrm{d}^{\mathrm{d}}$ \\
\hline$\Delta^{14} \mathrm{C}_{\mathrm{f}}(\% o)$ & final $\Delta^{14} \mathrm{C}$ value & -517.8 & 2.5 & average brine $\Delta^{14} \mathrm{C}_{\mathrm{DIC}}$ \\
\hline
\end{tabular}

${ }^{\text {a }}$ Northam et al. (1981); ${ }^{\mathrm{b}}$ Wiesenburg et al. (1985); ${ }^{\mathrm{c}}$ Reimer et al. (2009); ${ }^{\mathrm{d}}$ Wagner et al. (2009).

similar $\left(\delta^{13} \mathrm{C}_{\text {brineDOC }}-\delta^{13} \mathrm{C}_{\text {brineDIC }}=4 \pm 2 \%\right.$ o (NOSAMS), $6 \pm 2 \%$ (SkIO)). This $\delta^{13} \mathrm{C}$ similarity is not typical of open ocean basins and suggests a stronger linkage between these two reservoirs in Orca Basin than observed in other parts of the deep ocean. DOC is enriched within Orca Basin brine by approximately sevenfold compared to overlying seawater (Fig. 1a). This is a greater enrichment than is observed for DIC and points to the importance of in situ brine DOC sources. These sources could include incorporation of DOC produced from DIC by chemoautotrophy at the brine interface (Joye et al., 2009), microbial conversion of POC to DOC and disaggregation of POC to DOC. The $\delta^{13} \mathrm{C}$ value of DOC does not allow for a significant ${ }^{13} \mathrm{C}$-depleted source from methane oxidation as it is not more ${ }^{13} \mathrm{C}$-depleted than DOC in the water column above. A fraction of brine DOC is also likely to come from deep-ocean refractory DOC incorporated with bottom water upon brine formation, but this may only represent one seventh of total brine DOC.

Constructing a conservative mixing model of brine and seawater end-members would not be appropriate because DOC is likely to be a more dynamic reservoir than DIC with potential for microbial sinks as well as sources (Fig. 2b). Still, results of the DIC box model have implications for the radiocarbon contents of the in situ DOC sources. Box model results emphasize the importance of modern DIC sources (Sect. 4.2). Modern-day brine DIC and DOC have similar radiocarbon contents (Fig. 1c) but the greater enrichment of brine DOC concentrations compared to overlying seawater and the greater ${ }^{14} \mathrm{C}$-depletion of overlying DOC, and presumably original end-member DOC, compared to overlying DIC implies an even more dominant "modern" source to brine DOC than DIC. Along with evidence from $\delta^{13} \mathrm{C}$ values, this further minimizes the potential for microbial interaction with aged methane to create brine DOC.
Table 3. Modeled apportionment of DIC sources in Orca Basin brine.

\begin{tabular}{lllr}
\hline Modern brine DIC sources & Contribution & $\Delta^{14} \mathrm{C}(\%)$ & ${ }^{13} \mathrm{C}(\% \circ)$ \\
\hline original seawater DIC & $49 \pm 1 \%$ & $-93.1^{\mathrm{a}}$ & $+1^{\mathrm{a}}$ \\
oxidized sinking POC & $33 \pm 4 \%$ & IntCal09 $^{\mathrm{b}}$ & $-22^{\mathrm{c}}$ \\
oxidized methane from interface & $18 \pm 3 \%$ & IntCal09 $^{\mathrm{b}}$ & $-74^{\mathrm{d}}$ \\
oxidized methane from sediments & $0 \pm 3 \%$ & "aged"e & $-74^{\mathrm{d}}$ \\
\hline
\end{tabular}

${ }^{\text {a }}$ Overlying seawater from $2050 \mathrm{~m}$, Table $1 ;^{\mathrm{b}}$ Reimer et al. (2009); ${ }^{\mathrm{c}}$ Northam et al. (1981); ${ }^{\mathrm{d}}$ Wiesenburg et al. (1985); ${ }^{\mathrm{e}}$ assumed.

\section{Conclusions}

Both the concentration and isotopic composition of dissolved carbon reservoirs in Orca Basin brine appear to be stable over the past three decades. Modeled results point toward the importance of slow, cumulative and in situ microbial contributions to the inorganic carbon pool and emphasize the importance of the brine interface as the location of this microbial activity. Although both organic carbon and methane are implicated as the ultimate sources of brine DIC, box-modeled results show limited potential for contributions from the oxidization of methane diffusing upwards from sediments. The relative importance of individual DIC sources to Orca Basin brine is summarized in Table 3.

The isotopic composition of brine DOC is similar to brine DIC suggesting both a stronger coupling between these two reservoirs than is observed in overlying seawater and distinct sources and sinks for brine DOC compared to DIC. Stable carbon isotopic values only allow for a small DOC source from microbial incorporation of methane, unlike the proportionally important source expected for DIC. Aside from anaerobic methane oxidation, carbon isotopic evidence cannot indicate specific microbial pathways important in 
DOC or DIC cycling. It also cannot determine the limiting factor that prevents organic carbon remineralization by microbial sulfate reduction in Orca Basin brine. Further, microbial and compound-specific isotopic investigations of the brine and seawater-brine interface are needed to form a better understanding of specific microbial processes contributing to dissolved carbon storage in the Orca Basin brine.

Acknowledgements. We are grateful for the assistance of the crew and Shipboard Scientific Services Group of the R/V Atlantis and to Pete Girguis for enabling the collection of brine samples. The box model presented in this manuscript has been improved greatly from discussions with Bill Jenkins and Ann Pearson. This work was funded by the WHOI Postdoctoral Scholar program, NSF Cooperative Agreement for the Operation of a National Ocean Sciences Accelerator Mass Spectrometry Facility (OCE-0753487), and the US National Science Foundation's Emerging Frontiers program (award 0801741 to SBJ).

Edited by: S. Bouillon

\section{References}

Addy, S. K. and Behrens, E. W.: Time of accumulation of hypersaline anoxic brine in Orca Basin (Gulf of Mexico), Mar. Geol., 37, 241-252, 1980.

Antunes, A., Ngugi, D. K., and Stingl, U.: Microbiology of the Red Sea (and other) deep-sea anoxic brine lakes, Environ. Microbiol., 3, 416-433, doi:10.1111/j.1758-2229.2011.00264.x, 2011.

Beaupré, S. R., Druffel, E. R. M., and Griffin, S.: A low-blank photochemical extraction system for concentration and isotopic analyses of marine dissolved organic carbon, Limnol. Oceanogr.Meth., 5, 174-184, doi:10.4319/lom.2007.5.174, 2007.

Bouma, A. H. and Bryant, W. R.: Physiographic features on the northern Gulf of Mexico continental slope, Geo.-Mar. Lett, 14, 252-263, 1994.

Brandes, J. A.: Rapid and precise $\delta^{13} \mathrm{C}$ measurement of dissolved inorganic carbon in natural waters using liquid chromatography coupled to an isotope-ratio mass spectrometer, Limnol. Oceanogr.-Meth., 7, 730-739, 2009.

Currie, L. A., Kessler, J. D., Marolf, J. V., McNichol, A. P., Stuart, D. R., Donoghue, J. C., Donahue, D. J., Burr, G. S., and Biddulph, D.: Low-level (submicromole) environmental ${ }^{14} \mathrm{C}$ metrology, Nucl. Instrum. Meth. B, 172, 440-448, 2000.

Dickins, H. D. and Van Vleet, E. S.: Archaebacterial activity in the Orca Basin determined by the isolation of characteristic isopranyl ether-linked lipids, Deep-Sea Res., 39, 521-536, 1992.

Druffel, E. R. M. and Bauer, J. E.: Radiocarbon distributions in Southern Ocean dissolved and particulate organic matter, Geophys. Res. Lett., 27, 1495-1498, 2000.

Druffel, E. R. M., Williams, P. M., Bauer, J. E., and Ertel, J. R.: Cycling of dissolved and particulate organic matter in the open ocean, J. Geophys. Res., 97, 15639-15659, doi:10.1029/92JC01511, 1992.

Elder, K. L., McNichol, A. P., and Gagnon, A. R.: Reproducibility of seawater, inorganic and organic carbon ${ }^{14} \mathrm{C}$ results at NOSAMS, Radiocarbon, 40, 223-230, 1998.
Flower, B. P., Hastings, D. W., and Randle, N. J.: Paired AMS ${ }^{14} \mathrm{C}$ dates on planktic foraminifera from a Gulf of Mexico sediment core: An assessment of stratigraphic continuity, Radiocarbon, 53, 337-344, 2011.

Griffith, D. R., McNichol, A. P., Xu, L., McLaughlin, F. A., Macdonald, R. W., Brown, K. A., and Eglinton, T. I.: Carbon dynamics in the western Arctic Ocean: insights from full-depth carbon isotope profiles of DIC, DOC, and POC, Biogeosciences, 9, 1217-1224, doi:10.5194/bg-9-1217-2012, 2012.

Humphris, C. C.: Salt Movement on Continental Slope, Northern Gulf of Mexico, in Framework, Facies, and Oil-Trapping Characteristics of the Upper Continental Margin: Studies in Geology No. 7, edited by: Bouma, A. H., Moore, G. T., and Coleman, J. M., 69-85, American Association of Petroleum Geologists, Tulsa, Oklahoma, 1978.

Hurtgen, M. T., Lyons, T. W., Ingall, E. D., and Cruse, A. M.: Anomalous enrichments of iron monosulfide in euxinic marine sediments and the role of $\mathrm{H}_{2} \mathrm{~S}$ in iron sulfide transformations: Examples from Effingham Inlet, Orca Basin, and the Black Sea, Am. J. Sci., 299, 556-588, 1999.

Jenkins, W. J., Elder, K. L., Mcnichol, A. P., and Von Reden, K. F.: The passage of the bomb radiocarbon pulse into the Pacific Ocean, Radiocarbon, 52, 1182-1190, 2010.

Joye, S. B., MacDonald, I. R., Montoya, J. P., and Peccini, M.: Geophysical and geochemical signatures of Gulf of Mexico seafloor brines, Biogeosciences, 2, 295-309, doi:10.5194/bg-2-295-2005, 2005.

Joye, S. B., Samarkin, V. A., Orcutt, B. N., Macdonald, I. R., Hinrichs, K.-U., Elvert, M., Teske, A. P., Lloyd, K. G., Lever, M. A., Montoya, J. P. and Meile, C. D.: Metabolic variability in seafloor brines revealed by carbon and sulphur dynamics, Nat. Geosci., 2, 349-354, doi:10.1038/ngeo475, 2009.

Joye, S. B., Bowles, M. W., Samarkin, V. A., Hunter, K. S., and Niemann, H.: Biogeochemical signatures and microbial activity of different cold-seep habitats along the Gulf of Mexico deep slope, Deep-Sea Res. Pt. II, 57, 1990-2001, doi:10.1016/j.dsr2.2010.06.001, 2010.

LaRock, P. A., Lauer, R. D., Schwarz, J. R., Watanabe, K. K., and Wiesenburg, D. A.: Microbial biomass and activity distribution in an anoxic, hypersaline basin, Appl. Environ. Microb., 37, 466470, 1979.

Leventer, A., Williams, D. F., and Kennett, J. P.: Relationships between anoxia, glacial meltwater and microfossil preservation in the Orca Basin, Gulf of Mexico, Mar. Geol., 53, 23-40, doi:10.1016/0025-3227(83)90032-4, 1983.

Ma, L., Castro, M. C., Hall, C. M., and Walter, L. M.: Crossformational flow and salinity sources inferred from a combined study of helium concentrations, isotopic ratios, and major elements in the Marshall aquifer, Southern Michigan, Geochem. Geophy. Geosy., 6, 1-21, doi:10.1029/2005GC001010, 2005.

Macdonald, I. R., Reilly, J. F., Guinasso, N. L. J., Brooks, J. M., Carney, R. S., Bryant, W. R., and Bright, T. J.: Chemosynthetic mussels at a brine-filled pockmark in the Northern Gulf of Mexico., Science, 248, 1096-1099, doi:10.1126/science.248.4959.1096, 1990.

McNichol, A. P., Jones, G. A., Hutton, D. L., and Gagnon, A. R.: The rapid preparation of seawater $\Sigma \mathrm{CO}_{2}$ for radiocarbon analysis at the National Ocean Sciences AMS facility, Radiocarbon, 36, 237-246, 1994. 
Meckler, A. N., Schubert, C. J., Hochuli, P. A., Plessen, B., Birgel, D., Flower, B. P., Hinrichs, K.-U., and Haug, G. H.: Glacial to Holocene terrigenous organic matter input to sediments from Orca Basin, Gulf of Mexico - A combined optical and biomarker approach, Earth Planet. Sc. Lett., 272, 251-263, doi:10.1016/j.epsl.2008.04.046, 2008.

Mikucki, J. A., Pearson, A., Johnston, D. T., Turchyn, A. V., Farquhar, J., Schrag, D. P., Anbar, A. D., Priscu, J. C. and Lee, P. A.: A contemporary microbially maintained subglacial ferrous “Ocean”, Science, 324, 397-400, 2009.

Northam, M. A., Curry, D. J., Scalan, R. S., and Parker, P. L.: Stable carbon isotope ratio variations of organic matter in Orca Basin sediments, Geochim. Cosmochim. Ac., 45, 257-260, 1981.

Pilcher, R. S. and Blumstein, R. D.: Brine volume and salt dissolution rates in Orca Basin, Northeast Gulf of Mexico, AAPG Bull., 91, 823-833, 2007.

Reilly, J. F. J., Macdonald, I. R., Biegert, E. K., and Brooks, J. M.: Geologic controls on the distribution of chemosynthetic communities in the Gulf of Mexico, in Hydrocarbon migration and its near-surface expression: AAPG Memoir 66, edited by: Schumacher, D. and Abrams, M. A., 39-62, 1996.

Reimer, P. J., Baillie, M. G. L., Bard, E., Bayliss, A., Beck, J. W., Blackwell, P. G., Bronk Ramsey, C., Buck, C. E., Burr, G. S., Edwards, R. L., Friedrich, M., Grootes, P. M., Guilderson, T. P., Hajdas, I., Heaton, T. J., Hogg, A. G., Hughen, K. A., Kaiser, K. F., Kromer, B., McCormac, F. G., Manning, S. W., Reimer, R. W., Richards, D. W., Southon, J. R., Talamo, S., Turney, C. S. M., van der Plicht, J., and Weyhenmeyer, C. E.: IntCal09 and Marine09 radiocarbon age clibration curves, 0-50,000 years Cal BP, Radiocarbon, 51, 1111-1150, 2009.

Roberts, H. H. and Carney, R. S.: Evidence of episodic fluid, gas, and sediment venting on the northern Gulf of Mexico continental slope, Econ. Geol., 92, 863-879, 1997.

Sackett, W. M., Brooks, J. M., Bernard, B. B., Schwab, C. R., Chung, H., and Parker, R. A.: A Carbon inventory for Orca Basin brines and sediments, Earth Planet. Sc. Lett., 44, 73-81, 1979.

Santos, G. M., Southon, J. R., Griffin, S., Beaupre, S. R., and Druffel, E. R. M.: Ultra small-mass AMS ${ }^{14} \mathrm{C}$ sample preparation and analyses at KCCAMS/UCI Facility, Nucl. Instrum. Meth. B, 259, 293-302, doi:10.1016/j.nimb.2007.01.172, 2007.

Sheu, D.-D., Shakur, A., Pigott, J. D., Wiesenburg, D. A., Brooks, J. M., and Krouse, H. R.: Sulfur and oxygen isotopic compositions of dissolved sulfate in the Orca Basin: Implications for origin of the high-salinity brine and oxidation of sulfides at the brineseawater interface, Mar. Geol., 78, 303-310, doi:10.1016/00253227(88)90115-6, 1988.
Shokes, R. F., Trabant, P. K., Presley, B. J., and Reid, D. F.: Anoxic, hypersaline basin in the Northern Gulf of Mexico, Science, 196, 1443-1446, 1977.

Stuiver, M. and Polach, H. A.: Reporting of ${ }^{14}$ C Data, Radiocarbon, 19, 355-363, 1977.

Trabant, P. K. and Presley, B. J.: Orca Basin, Anoxic Depression on the Continental Slope, Northwest Gulf of Mexico, in Framework, Facies, and Oil-Trapping Characteristics of the Upper Continental Margin: Studies in Geology No. 7, edited by: Bouma, A. H., Moore, G. T., and Coleman, J. M., 303-311, American Association of Petroleum Geologists, Tulsa, Oklahoma, 1978.

Trefry, J. H., Presley, B. J., Keeney-Kennicutt, W. L., and Trocine, R. P.: Distribution and chemistry of manganese, iron, and suspended particulates in Orca Basin, Geo.-Mar. Lett, 4, 125-130, doi:10.1007/BF02277083, 1984.

Tribovillard, N., Bout-Roumazeilles, V., Algeo, T., Lyons, T. W., Sionneau, T., Montero-Serrano, J. C., Riboulleau, A., and Baudin, F.: Paleodepositional conditions in the Orca Basin as inferred from organic matter and trace metal contents, Mar. Geol., 254, 62-72, doi:10.1016/j.margeo.2008.04.016, 2008.

Tuovila, B. J., Dobbs, F. C., LaRock, P. A., and Siegel, B. Z.: Preservation of ATP in hypersaline environments, Appl. Environ. Microb., 53, 2749-2753, 1987.

Van Cappellen, P., Viollier, E., Roychoudhury, A., Clark, L., Ingall, E., Lowe, K., and DiChristina, T.: Biogeochemical cycles of manganese and iron at the oxic-anoxic transition of a stratified marine basin (Orca Basin, Gulf of Mexico), Environ. Sci. Technol., 32, 2931-2939, 1998.

Wagner, A. J., Guilderson, T. P., Slowey, N. C., and Cole, J. E.: Pre-bomb surface water radiocarbon of the Gulf of Mexico and Caribbean as recorded in hermatypic corals, Radiocarbon, 51, 947-954, 2009.

Wiesenburg, D. A., Brooks, J. M., and Bernard, B. B.: Biogenic hydrocarbon gases and sulfate reduction in the Orca Basin Brine, Geochim. Cosmochim. Ac., 49, 2069-2080, doi:10.1016/00167037(85)90064-X, 1985.

Wong, G. T. F., Takayanagi, K., and Todd, J. F.: Dissolved iodine in waters overlying and in the Orca Basin, Gulf of Mexico, Mar. Chem., 17, 177-183, 1985.

Zeebe, R. E.: On the Molecular diffusion coefficients of dissolved $\mathrm{CO}_{2}, \mathrm{HCO}_{3}^{-}$, and $\mathrm{CO}_{3}^{2-}$ and their dependence on isotopic mass, Geochim. Cosmochim. Ac., 75, 2483-2498, doi:10.1016/j.gca.2011.02.010, 2011. 